Dhaka Univ. J. Biol. Sci. 19(2): 111-118, 2010 (July)

\title{
EFFECTS OF WATER DEPTH ON THE GROWTH OF NELUMBO NUCIFERA GAERTN. SEEDLINGS
}

\author{
Md. Almujaddade Alfasane, Moniruzzaman KhondKer \\ AND Z. N. TAHMIDA BEGUM \\ Department of Botany, University of Dhaka, Dhaka-1000, Bangladesh
}

Key words: Water depth, Limnological factors, Growth, Nelumbo nucifera

\begin{abstract}
Water depth showed significant effect on the growth of Nelumbo nucifera Gaertn. in deep and shallow water culture pits. In deep water culture pit, the leaf area showed its highest growth rate of $21.84 \pm 2.89 \mathrm{~cm}^{2} /$ day in summer and petiole length showed highest growth rate of $0.34 \pm 0.10 \mathrm{~cm} /$ day in monsoon. The plantlets grown in shallow water culture pit showed highest growth rate of leaf area of $8.75 \pm 0.91 \mathrm{~cm}^{2} /$ day in summer and the length of the petiole was highest in monsoon $(0.25 \pm 0.03 \mathrm{~cm} /$ day $)$. Comparatively highest growth was observed in deep water culture pit rather than that of shallow water. Highest growth of the plant and flowering were found to be associated with higher water depth (100 $\mathrm{cm}$ ) where the plant grew up to a height of about $1.5 \mathrm{~m}$ and maximum leaf diameter was $50 \mathrm{~cm}$. Poor growth of the plant with no flowering was in shallow water depth $(20 \mathrm{~cm})$ where maximum height of the plant was about $0.5 \mathrm{~m}$ and leaf diameter was $25 \mathrm{~cm}$. Although the concentrations of $\mathrm{NO}_{3}-\mathrm{N}$, soluble reactive phosphorus, soluble reactive silicate, planktonic chl $a$ and phaeopigment were in higher amount in shallow water culture pit but due to shallow depthness plant showed poor growth and no flowering.
\end{abstract}

\section{Introduction}

Water depth has been considered as a regulatory factor for many water quality parameters. Water temperature and dissolved oxygen vary with depth as well as with the time of day. The depth of light penetration, which is influenced by turbidity, has an effect on the productivity of plants in an aquatic ecosystem. Various depths in a lake or river host different assemblages of benthic (bottom-dwelling) organisms. Plankton and fish move from one depth to another based on changing environmental conditions. In Bangladesh very few works on macrophytic vegetation have been carried out.(1-4) Recently Alfasane et al.(5-6) have studied the relationships between growth rate and limnological factors of Nelumbo nucifera Gaertn. and Euryale ferox Salisb. Biochemical compositions of the seeds of E. ferox and N. nucifera were also studied.(7-8) No research work has been carried out so far on the effects of water depth on the growth of $N$. nucifera seedlings in Bangladesh. However, similar researches had been carried out in other countries. ${ }^{(9-17)}$ The present study has, therefore, been undertaken to carry out the effects of water depth on the growth of N. nucifera seedlings.

*Corresponding author. 


\section{Materials and Methods}

The experiment was carried out in the culture pits of Department of Botany, University of Dhaka between 2005 and 2007. Seedlings of Nelumbo nucifera were obtained via seeds sown in $1: 1$ cow-dung compost and loamy soil. Collection and germination of seeds of $N$. nucifera were described by Alfasane et al.(5) Two experiments were conducted. For the first experiment which was described by Alfasane et al.(5), deep water culture pit measuring $3 \times 2 \mathrm{~m}$ was filled with transparent underground water up to $100 \mathrm{~cm}$ for the first experiment and shallow water culture pit measuring $1.5 \times 0.75 \mathrm{~m}$ was filled up to 25 $\mathrm{cm}$ for the second experiment. Eight young seedlings (3 months old) of N. nucifera were transferred to the deep water culture pit and immediately after transplantation some tap water was added in the tank in such a way that only the leaves of the plants remain afloat. The water depth was adjusted everyday looking at the growth of the plants. Eight plantlets were transferred to another shallow water culture pit and cultured to see the effect of depth on the plant and to compare the effects of water depth on the growth of $N$. nucifera in both the culture pits. The growth measurement was carried out on randomly selected petioles $(n=8)$ and leaves $(n=32)$ of the plants of both the culture pits.

During the experiments data on relative humidity, total rainfall, day length (sunshine hours), PAR (photosynthetic active radiation), air and water temperature, $\mathrm{pH}, \mathrm{DO}$ (dissolved oxygen), soluble reactive silicate (SRS), alkalinity, nitrate-nitrogen ( $\left.\mathrm{NO}_{3}-\mathrm{N}\right)$, SRP (soluble reactive phosphorus) and phytoplankton biomass were studied. Methods applied to measure these limnological parameters have been elaborated in Alfasane et al. ${ }^{(5)}$ Seasonal mean values and ranges of the data of two culture pits are presented in Table 1. Pearson correlation study was made (SPSS program) to find the relationships between the measured limnological variables and the growth of petiole and leaf area of the plant of both the culture pits (Table 2).

\section{Results and Discussion}

The present study showed that germination of the seeds occurred within the water depth of about $25 \mathrm{~cm}$. Similar observation was found for the germination of the seeds of Trapa bicornis L. within the water depth of $20-25 \mathrm{~cm}$. ${ }^{(13)}$

Results showing highest growth and flowering of $N$. nucifera in deep water culture pit associated with a water depth of $100 \mathrm{~cm}$ are presented in Figs. 1A-C. Poor growth of the plant with no flowering in shallow water culture pit is presented in Figs. 1D-F. In the deep water culture pit the plant grew up to a height of about $1.5 \mathrm{~m}$ and the leaves were as large as $50 \mathrm{~cm}$ in diameter. On the other hand, shallow water showed maximum height of the plant of about $0.5 \mathrm{~m}$ and leaves diameter of about $25 \mathrm{~cm}$.

In both the culture pits variation of different parameters were observed in different seasons such as in deep water culture pit(5), the leaf area showed its maximum average highest growth rate of $21.84 \pm 2.89 \mathrm{~cm}^{2} /$ day in summer. A medium range growth rate was 
observed during the monsoon $\left(18.31 \pm 0.98 \mathrm{~cm}^{2} /\right.$ day). In winter the growth rate was $1.71 \pm$ $0.55 \mathrm{~cm}^{2} /$ day whereas autumn showed poor growth of the plant $\left(2.33 \pm 0.29 \mathrm{~cm}^{2} /\right.$ day; Fig. 2). Another aquatic macrophyte Euryale ferox also showed increased growth rate of leaf area in summer( ${ }^{(6)}$. Petiole length showed highest growth rate of $0.34 \pm 0.10 \mathrm{~cm} /$ day in monsoon. The summer season showed a medium growth in the length of the petiole $(0.29 \pm 0.05 \mathrm{~cm} /$ day). In autumn, the petiole length grew at a rate of $0.25 \pm 0.07 \mathrm{~cm} /$ day. Least growth rate of the petiole was observed in winter $(0.22 \pm 0.05 \mathrm{~cm} /$ day; Fig. 2). Similar type of observation was also recorded in E. ferox ${ }^{(6)}$.
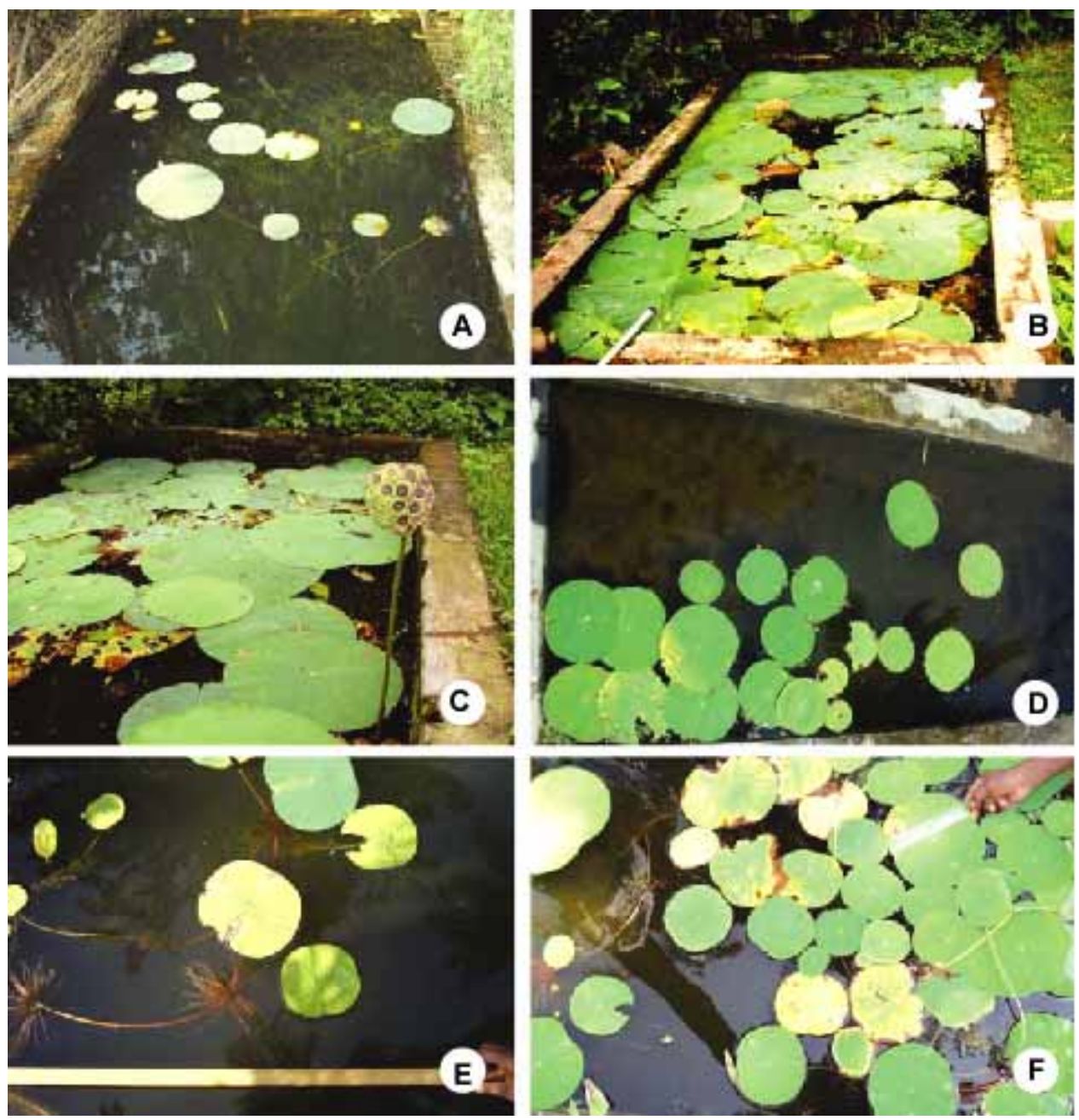

Figs. 1A-F: A-C. Growing stage of seedlings of Nelumbo nucifera in the deep water culture pit with large leaves, flowering and fruiting stage. D-F. Plant grown in shallow water culture pit of Nelumbo nucifera with small leaves and no flowering and fruiting stage. 
The plantlets grown in shallow water culture pit showed highest growth rate of leaf area of $8.75 \pm 0.91 \mathrm{~cm}^{2} /$ day in summer. In monsoon the growth rate was medium (5.46 \pm $0.67 \mathrm{~cm}^{2} /$ day). In autumn the growth rate was $1.15 \pm 0.15 \mathrm{~cm}^{2} /$ day and the least growth was observed in winter $\left(0.95 \pm 0.26 \mathrm{~cm}^{2} /\right.$ day $)$. The length of the petiole was highest in monsoon $(0.25 \pm 0.03 \mathrm{~cm} /$ day $)$. A medium growth of the petiole was observed in summer $(0.20 \pm 0.03 \mathrm{~cm} /$ day $)$. The growth in the petiole length in autumn was $0.15 \pm 0.01 \mathrm{~cm} /$ day . Lowest growth of the same was observed in winter $(0.09 \pm 0.02 \mathrm{~cm} /$ day; Fig. 2). In contrast to shallow water culture pit highest growth was observed in deep water culture pit. Highest growth and flowering were found to be associated with a water depth of 100 $\mathrm{cm}$. That Vallisneria natans showed an optimal clonal growth at water depths of $110-160$ $\mathrm{cm}$ was reported by Xiao et al.(9) Salter et al.(10) also examined the response of 5-monthold Melaleuca ericifolia Sm. (Swamp paperbark) seedlings to three water depths (exposed, waterlogged and submerged) at three salinities $(2,49$ and $60 \mathrm{dS} / \mathrm{m})$ and they found that
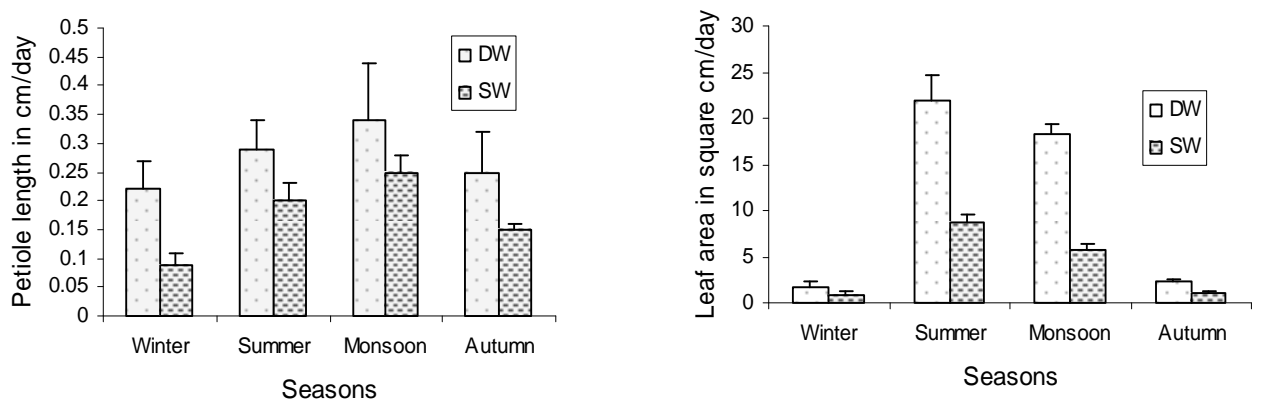

Fig. 2. Growth rate of Nelumbo nucifera in different seasons for deep water (DW, Alfasane et al. ${ }^{5}$ ) and shallow water (SW) culture pits (petiole length in $\mathrm{cm} /$ day, leaf area in $\mathrm{cm}^{2} /$ day).

increasing water depth at the lowest salinity did not affect survival, but strongly inhibited seedling growth. Strand and Weisner ${ }^{(12)}$ reported that under deep water condition Myriophyllum spicatum exhibited increase in its height and branch length, and decreased branch number. Rea et al.(14) also showed that the area occupied by floatingleaved macrophytes increased from 3.2 to 19.9 ha, when macrophytes occupied $84.1 \%$ of the area $\leq 2 \mathrm{~m}$ deep and $56.3 \%$ of the area $3 \mathrm{~m}$ deep. The rates of macrophyte development were consistently slower in areas of greater water depth and greater fetch. Myriophyllum variifolium J. Hooker and Eleocharis acuta R. Br. showed morphological changes in different water depths. ${ }^{(16)}$

Throughout the study period, climatic data(5) showed that seasonal mean values of PAR were highest $\left(776.83 \mu \mathrm{E} / \mathrm{m}^{2} / \mathrm{sec}\right)$ in summer and lowest $\left(620.28 \mu \mathrm{E} / \mathrm{m}^{2} / \mathrm{sec}\right)$ in winter. The highest and lowest seasonal mean sunshine hour values were 12.84 and $10.74 \mathrm{hr}$ in monsoon and autumn, respectively. The highest $(213.19 \mathrm{~mm})$ mean values of rainfall were recorded during monsoon and lowest $(2.28 \mathrm{~mm})$ were recorded during winter. On 
the other hand, the highest $(79.59 \%)$ mean values of humidity were recorded during monsoon and the lowest (55.83\%) values were recorded during summer.

The results presented in Table 1 showed that the highest and lowest seasonal mean air temperatures were 33.92 and $25.49^{\circ} \mathrm{C}$ in summer and winter, respectively. The highest seasonal mean water temperature was $31.58^{\circ} \mathrm{C}$ for two culture pits in summer. The lowest seasonal mean temperature was 24.28 and $24.07^{\circ} \mathrm{C}$ for deep water and shallow water culture pits, respectively. The mean pH fluctuated from $6.67-7.09$ and $6.68-7.04$ for deep water and shallow water culture pits, respectively in different seasons of the present study. The highest seasonal mean values of alkalinity recorded were 4.10 and

Table 1. Seasonal mean values of different limnological parameters for Nelumbo nucifera in deep water (DW, Alfasane et al..$^{5}$ ) and shallow water (SW) culture pits.

\begin{tabular}{|c|c|c|c|c|c|c|c|c|}
\hline \multirow[t]{2}{*}{ Parameters } & \multicolumn{2}{|c|}{$\begin{array}{c}\text { Winter (late } \\
\text { November-February) }\end{array}$} & \multicolumn{2}{|c|}{$\begin{array}{c}\text { Summer } \\
\text { (March-May) }\end{array}$} & \multicolumn{2}{|c|}{$\begin{array}{c}\text { Monsoon (June- } \\
\text { early October) }\end{array}$} & \multicolumn{2}{|c|}{$\begin{array}{c}\text { Autumn (late } \\
\text { October- November) }\end{array}$} \\
\hline & DW & SW & $\mathrm{DW}$ & SW & DW & SW & DW & SW \\
\hline Air temp. $\left({ }^{\circ} \mathrm{C}\right)$ & $\begin{array}{l}25.49 \\
\pm 4.02\end{array}$ & $\begin{array}{l}25.49 \\
\pm 4.02\end{array}$ & $\begin{array}{l}33.92 \\
\pm 2.30\end{array}$ & $\begin{array}{l}33.92 \\
\pm 2.30\end{array}$ & $\begin{array}{l}32.00 \\
\pm 2.24\end{array}$ & $\begin{array}{l}32.00 \\
\pm 2.24\end{array}$ & $\begin{array}{l}33.50 \\
\pm 2.01\end{array}$ & $\begin{array}{l}33.50 \\
\pm 2.01\end{array}$ \\
\hline Water temp. $\left({ }^{\circ} \mathrm{C}\right)$ & $\begin{array}{l}24.28 \\
\pm 3.89\end{array}$ & $\begin{array}{l}24.07 \\
\pm 4.05\end{array}$ & $\begin{array}{l}31.58 \\
\pm 1.95\end{array}$ & $\begin{array}{l}31.58 \\
\pm 2.14\end{array}$ & $\begin{array}{l}29.93 \\
\pm 1.99\end{array}$ & $\begin{array}{l}30.11 \\
\pm 1.66\end{array}$ & $\begin{array}{l}30.75 \\
\pm 1.15\end{array}$ & $\begin{array}{l}30.75 \\
\pm 1.53\end{array}$ \\
\hline $\mathrm{pH}$ & $\begin{array}{l}6.95 \\
\pm 0.22\end{array}$ & $\begin{array}{l}7.04 \\
\pm 0.13\end{array}$ & $\begin{array}{l}6.67 \\
\pm 0.07\end{array}$ & $\begin{array}{l}6.68 \\
\pm 0.12\end{array}$ & $\begin{array}{l}6.94 \\
\pm 0.24\end{array}$ & $\begin{array}{l}6.92 \\
\pm 0.09\end{array}$ & $\begin{array}{l}7.09 \\
\pm 0.06\end{array}$ & $\begin{array}{l}6.83 \\
\pm 0.12\end{array}$ \\
\hline Alkalinity (meq/l) & $\begin{array}{l}3.86 \\
\pm 0.27\end{array}$ & $\begin{array}{l}3.67 \\
\pm 0.39\end{array}$ & $\begin{array}{l}4.10 \\
\pm 0.61\end{array}$ & $\begin{array}{l}3.84 \\
\pm 0.80\end{array}$ & $\begin{array}{l}2.97 \\
\pm 0.47\end{array}$ & $\begin{array}{l}1.80 \\
\pm 0.41\end{array}$ & $\begin{array}{l}3.45 \\
\pm 0.34\end{array}$ & $\begin{array}{l}2.84 \\
\pm 0.37\end{array}$ \\
\hline $\mathrm{DO}(\mathrm{mg} / \mathrm{l})$ & $\begin{array}{l}11.08 \\
\pm 0.94\end{array}$ & $\begin{array}{l}7.67 \\
\pm 0.77\end{array}$ & $\begin{array}{l}10.00 \\
\pm 1.72\end{array}$ & $\begin{array}{l}8.65 \\
\pm 0.76\end{array}$ & $\begin{array}{l}5.65 \\
\pm 0.97\end{array}$ & $\begin{array}{l}4.87 \\
\pm 1.67\end{array}$ & $\begin{array}{l}10.26 \\
\pm 1.15\end{array}$ & $\begin{array}{l}8.02 \\
\pm 0.15\end{array}$ \\
\hline $\mathrm{NO}_{3}-\mathrm{N}(\mu \mathrm{g} / \mathrm{l})$ & $\begin{array}{l}95.28 \\
\pm 65.17\end{array}$ & $\begin{array}{l}197.43 \\
\pm 66.40\end{array}$ & $\begin{array}{l}108.72 \\
\pm 43.13\end{array}$ & $\begin{array}{l}135.84 \\
\pm 47.18\end{array}$ & $\begin{array}{l}60.97 \\
\pm 41.93\end{array}$ & $\begin{array}{l}106.02 \\
\pm 55.57\end{array}$ & $\begin{array}{l}58.55 \\
\pm 37.54\end{array}$ & $\begin{array}{l}80.39 \\
\pm 54.41\end{array}$ \\
\hline $\mathrm{SRP}(\mu \mathrm{g} / \mathrm{l})$ & $\begin{array}{l}132.93 \\
\pm 49.49\end{array}$ & $\begin{array}{l}287.56 \\
\pm 75.03\end{array}$ & $\begin{array}{l}113.46 \\
\pm 65.34\end{array}$ & $\begin{array}{l}599.93 \\
\pm 178.21\end{array}$ & $\begin{array}{l}87.96 \\
\pm 60.05\end{array}$ & $\begin{array}{l}268.15 \\
\pm 64.35\end{array}$ & $\begin{array}{l}138.81 \\
\pm 29.04\end{array}$ & $\begin{array}{l}292.22 \\
\pm 43.69\end{array}$ \\
\hline SRS (mg/l) & $\begin{array}{l}85.22 \\
\pm 25.08\end{array}$ & $\begin{array}{l}82.85 \\
\pm 23.74\end{array}$ & $\begin{array}{l}80.76 \\
\pm 37.33\end{array}$ & $\begin{array}{l}49.46 \\
\pm 18.95\end{array}$ & $\begin{array}{l}74.52 \\
\pm 25.29\end{array}$ & $\begin{array}{l}15.36 \\
\pm 5.48\end{array}$ & $\begin{array}{l}77.12 \\
\pm 10.47\end{array}$ & $\begin{array}{l}50.59 \\
\pm 17.06\end{array}$ \\
\hline Chl $a(\mu \mathrm{g} / \mathrm{l})$ & $\begin{array}{l}35.25 \\
\pm 29.85\end{array}$ & $\begin{array}{l}55.38 \\
\pm 30.73\end{array}$ & $\begin{array}{l}102.34 \\
\pm 130.95\end{array}$ & $\begin{array}{l}165.50 \\
\pm 113.04\end{array}$ & $\begin{array}{l}24.32 \\
\pm 24.93\end{array}$ & $\begin{array}{l}60.75 \\
\pm 96.57\end{array}$ & $\begin{array}{l}24.99 \\
\pm 8.85\end{array}$ & $\begin{array}{l}66.53 \\
\pm 70.35\end{array}$ \\
\hline Phaeo. $(\mu \mathrm{g} / \mathrm{l})$ & $\begin{array}{l}6.85 \\
\pm 5.65\end{array}$ & $\begin{array}{l}10.54 \\
\pm 6.15\end{array}$ & $\begin{array}{l}24.89 \\
\pm 36.98\end{array}$ & $\begin{array}{l}27.83 \\
\pm 29.00\end{array}$ & $\begin{array}{l}5.67 \\
\pm 5.64\end{array}$ & $\begin{array}{l}16.21 \\
\pm 30.92\end{array}$ & $\begin{array}{l}5.67 \\
\pm 2.57\end{array}$ & $\begin{array}{l}8.13 \\
\pm 9.90\end{array}$ \\
\hline
\end{tabular}

DW - Deep water culture pit, SW - Shallow water culture pit.

$3.84 \mathrm{meq} / \mathrm{l}$ during summer for deep water and shallow water culture pits, respectively and the lowest $(2.97 \mathrm{meq} / \mathrm{l}$ in deep water and $1.80 \mathrm{meq} / \mathrm{l}$ in shallow water culture pits) were recorded during monsoon. Dissolved oxygen concentration of the studied habitats ranged from $5.65-11.08 \mathrm{mg} / \mathrm{l}$ and $4.87-8.65 \mathrm{mg} / \mathrm{l}$ for deep water and shallow water culture pits, respectively. The concentration of $\mathrm{NO}_{3}-\mathrm{N}$ varied from $58.55-108.72 \mu \mathrm{g} / \mathrm{l}$ and 
$80.39-197.43 \mu \mathrm{g} / \mathrm{l}$ for deep water and shallow water culture pits, respectively. The soluble reactive phosphorus exhibited highly fluctuating pattern over the study period and among the culture pits. The concentration ranged from $87.96-138.81 \mu \mathrm{g} / \mathrm{l}$ and 268.15 - $599.93 \mu \mathrm{g} / \mathrm{l}$, for deep water and shallow water culture pits, respectively. In the deep water culture pit, SRS ranged from $74.52-85.22 \mathrm{mg} / \mathrm{l}$ and in shallow water culture pit from 15.36 - $82.85 \mathrm{mg} / \mathrm{l}$. The concentration of planktonic chl $a$ varied from $24.32-102.34$ $\mu \mathrm{g} / \mathrm{l}$ and $55.38-165.50 \mu \mathrm{g} / \mathrm{l}$ for deep water and shallow water culture pits, respectively. Phaeopigment concentration varied from 5.67 - $24.89 \mu \mathrm{g} / \mathrm{l}$ and 8.13 - $27.83 \mu \mathrm{g} / \mathrm{l}$ for deep water and shallow water culture pits, respectively. Emergent macrophyte (Cladium mariscus) showed significant differences in the limnological environment in deeper $(1.0 \mathrm{~m})$ and in shallower $(0.4 \mathrm{~m})$ water zones of the Spanish National Park, Las Tablas de Daimiel.(11)

Correlation studies between the growth and limnological variables for deep water culture pit ${ }^{(5)}$ showed that the petiole length relates positively with rainfall, humidity and $\mathrm{pH}$ and leaf area showed positive correlation with PAR, day length, rainfall, humidity, air temperature, water temperature, $\mathrm{NO}_{3}-\mathrm{N}$, planktonic chl $a$ and phaeopigment. Among these parameters positive correlation between leaf area and day length was found to be significant at 5\% level (Table 2). On the other hand, shallow water culture pit for $N$. nucifera showed that the petiole length positively correlated with PAR, day length, rainfall, humidity, air temperature, water temperature and SRP and leaf area showed positive correlation with PAR, day length, rainfall, humidity, air temperature, water temperature, alkalinity, SRP and planktonic chl $a$ (Table 2).

Table 2. Pearson correlation between limnological parameters and growth rate of Nelumbo nucifera (data extracted from SPSS programme).

\begin{tabular}{|c|c|c|c|c|c|c|c|c|c|}
\hline \multirow{3}{*}{$\begin{array}{c}\text { Limnological } \\
\text { parameters }\end{array}$} & \multicolumn{4}{|c|}{ Growth rate } & \multirow{3}{*}{$\begin{array}{l}\text { Limnological } \\
\text { parameters }\end{array}$} & \multicolumn{4}{|c|}{ Growth rate } \\
\hline & \multicolumn{2}{|c|}{ Petiole length } & \multicolumn{2}{|c|}{ Leaf area } & & \multicolumn{2}{|c|}{ Petiole length } & \multicolumn{2}{|c|}{ Leaf area } \\
\hline & DW & SW & DW & SW & & DW & SW & DW & SW \\
\hline PAR & -0.818 & +0.388 & +0.682 & +0.811 & Alkalinity & -0.904 & -0.637 & -0.019 & +0.072 \\
\hline Day length & -0.195 & +0.872 & $+0.976^{*}$ & +0.910 & $\mathrm{DO}$ & -0.569 & -0.595 & -0.567 & -0.006 \\
\hline Rainfall & +0.452 & +0.921 & +0.673 & +0.482 & $\mathrm{NO}_{3}-\mathrm{N}$ & -0.853 & -0.568 & +0.269 & -0.120 \\
\hline Humidity & +0.811 & +0.689 & +0.238 & +0.009 & SRP & -0.233 & +0.205 & -0.383 & +0.801 \\
\hline Air temp. & -0.229 & +0.656 & +0.565 & +0.563 & SRS & -0.501 & -0.955 & -0.807 & -0.491 \\
\hline Water temp. & -0.248 & +0.649 & +0.619 & +0.513 & Chl $a$ & $-0.951^{*}$ & -0.087 & +0.624 & +0.563 \\
\hline $\mathrm{pH}$ & +0.797 & -0.806 & -0.776 & -0.282 & Phaeopigment & -0.935 & -0.777 & +0.663 & -0.539 \\
\hline
\end{tabular}

${ }^{*}$ Correlation is significant at the 0.05 level (2- tailed). DW = Deep water culture pit (Alfasane $e t$ al. ${ }^{5}$ ), $\mathrm{SW}=$ Shallow water culture pit.

The present study reveals that $\mathrm{pH}$, alkalinity and dissolved oxygen were in higher range in deep water culture pit rather than that of shallow water culture pit. On the other hand, the concentration range of $\mathrm{NO}_{3}-\mathrm{N}, \mathrm{SRP}$, planktonic chl $a$ and phaeopigmet were in higher range in shallow water culture pit rather than that of deep water culture pit. The 
concentration of maximum mean values of SRS in the two culture pits were nearly same. These results clearly indicate that higher range of $\mathrm{NO}_{3}-\mathrm{N}$, SRP and SRS did not influence positively in petiole length and leaf size of $N$. nucifera and failed to produce flowering and fruiting in shallow water culture pit. But in contrast to the deep water culture pit showed highest growth and flowering under lower concentrations of $\mathrm{NO}_{3}-\mathrm{N}, \mathrm{SRP}, \mathrm{SRS}$, planktonic chl $a$ and phaeopigment rather than that of shallow water culture pit.

\section{References}

1. Islam AKM Nurul 1993. Limnology and pollution of wetlands. In: Nishat, A., Hussain, Z., Roy, M.K. and Karim, A. (eds.), Freshwater Wetlands in Bangladesh: Issues and approaches for management. IUCN, Bangladesh, pp. 123-146.

2. Khondker M, AKM Nurul Islam and AD Makhnun 1993. Study of the growth of a floating macrophyte. J. Asiatic Soc. Bangladesh (Sci.) 19(2): 103-108.

3. Khondker M, AKM Nurul Islam and AD Makhnun 1994. Lemna perpusilia: Screening on habitat limnology. Bangladesh J. Bot. 23(1): 99-106.

4. Khondker M, ZNT Begum and MA Alfasane 2004. Growth and regeneration of Neptunia natans (L.f.) Druce and Euryale ferox Salisb. Bangladesh J. Bot. 33(1): 35-39.

5. Alfasane MA, M Khondker and ZNT Begum 2009. Effects of some limnological factors on the growth of Nelumbo nucifera Gaertn. Bangladesh J. Bot. 38(2): 133-138.

6. Alfasane MA, M Khondker and ZNT Begum 2010. Relationships between the growth of Euryale ferox Salisb. and some limnological parameters. Dhaka Univ. J. Biol. Sci. 19(1): 41-46.

7. Alfasane MA, M Khondker and ZNT Begum, LA Banu, MM Rahman and UF Shahjadee 2008. Fruit production and biochemical aspects of seeds of Euryale ferox Salisb. under ex-situ conditions. Bangladesh J. Bot. 37(2): 179-181.

8. Alfasane MA, M Khondker and ZNT Begum 2009. Biochemical composition of the seeds of Nelumbo nucifera Gaertn. Dhaka Univ. J. Biol. Sci. 18(1): 83-85.

9. Xiao K, D Yu and Z Wu 2007. Differential effects of water depth and sediment type on clonal growth of the submersed macrophyte Vallisneria natans. Hydrobiologia 589(1): 265-272

10. Salter J, K Morris, PCE Bailey and PI Boon 2007. Interactive effects of salinity and water depth on the growth of Melaleuca ericifolia Sm. (Swamp paperbark) seedlings. Aquatic Botany 86(3) : 213-222

11. Angeler DG, S Sánchez-Carrillo, MA Rodrigo, O Viedma and M Alvarez-Cobelas 2005. On the Importance of Water Depth, Macrophytes and Fish in Wetland Picocyanobacteria Regulation. Hydrobiologia 541(1): 23-32

12. Strand JA and SEB Weisner 2001. Morphological plastic responses to water depth and wave exposure in an aquatic plant (Myriophyllum spicatum). Journal of Ecology. 89(2): 166-175.

13. Arima S, MA Hoque and S Agarie 1998. Effects of shading and water depth on the growth of water chestnut seedling. Jpn. J. Crop Sci. 67(2): P-15.

14. Rea TE, DJ Karapatakis, KK Guy, JE Pinder and HE Mackey Jr 1998. The relative effects of water depth, fetch and other physical factors on the development of macrophytes in a small southeastern US pond. Aquatic Botany. 61(4): 289-299 
15. Rea N and GG Ganf 1994. Water depth changes and biomass allocation in two contrasting macrophytes. Aust. J. Marine and Freshwater Res. 45(8): 1459-1468.

16. Blanch SJ and MA Brock 1994. Effects of grazing and depth on two wetland plant species. Australian Journal of Marine and Freshwater Research 45(8): 1387-1394.

17. Waters I and JM Shay 1991. A field study of the effects of water depth, order of emergence and flowering on the growth of Typha glauca shoots using the Richards model. Aquatic Botany. 39(3-4) : 231-242.

(Manuscript received on 13 October, 2009; revised on 1 November, 2009) 